\title{
Synthesis and properties of aromatic 1,3-diketones and bis-(1,3-diketones) obtained from acetophenone and phtalic acids esters
}

\author{
Jan Zawadiak, Marek Mrzyczek* and Tomasz Piotrowski \\ Faculty of Chemistry, Silesian University of Technology, Krzywoustego 4, Gliwice, 44-100, Poland \\ ${ }^{*}$ Corresponding author at: Faculty of Chemistry, Silesian University of Technology, Krzywoustego 4, Gliwice, 44-100, Poland. Tel.: +48.32.2372971; \\ fax: +48.32.2371032. E-mail address: marek.mrzyczek@polsl.pl (M. Mrzyczek).
}

\begin{tabular}{l} 
ARTICLE INFORMATION \\
\hline Received: 14 March 2011 \\
Received in revised form: 07 April 2011 \\
Accepted: 08 April 2011 \\
Online: 30 September 2011 \\
KEYWORDS \\
1,3-Diketones \\
Tautomerism \\
Bis-(1,3-diketones) \\
UV/Vis spectroscopy \\
Solvent effect \\
Sunscreens
\end{tabular}

\section{Introduction}

Aromatic 1,3-diketones significantly absorb UV-A radiation $(\lambda=320-400 \mathrm{~nm})$ and are therefore used as sunscreens in cosmetics. Aromatic 1,3-diketones owe this feature to the formation of an intramolecular hydrogen bond in the enol tautomer (Scheme 1). Currently, 1-(4'-tert-butylphenyl)-3-(4"methoxyphenyl)-propane-1,3-dione is one of the few UV-A sunscreens approved both in Europe and in the USA [1].

The keto-enol equilibrium in 1,3-diketones strongly favors the enol form, and only very polar solvents or steric hindrance cause a slight shift of the equilibrium to the keto form [2]. These compounds also form complexes with metals, a feature which makes these compounds attractive for use in many applications. For example, a complex of a 1,3-diketone with zinc is used as a PVC stabilizer [3] and vulcanization activator [4].

Aromatic 1,3-diketones containing a 1,3-diphenylpropane1,3-dione (1) moiety are synthesized by the condensation of an acetophenone derivative and a substituted ester of benzoic acid (Scheme 2).

Use of phthalic acids esters instead of benzoates leads to aromatic bis-(1,3-diketones). Few studies concerning such compounds have been published to date, and these papers mainly describe the chelating properties of bis-(1,3-diketones) [5-7]. These compounds form metal complexes, and two chelating centers can form organometallic polymers or triangles [6]. Only two publications have investigated the spectroscopic properties of aromatic bis-(1,3-diketones) [8,9]. Because these compounds contain two 1,3-dicarbonyl moieties, they might prove to be superior UV absorbing agents, therefore research of UV absorption properties of bis-(1,3-diketones) was the main objective of this work.

\section{Experimental}

\subsection{Instrumentation}

The melting points were determined in an open capillary tube on a Stanford Research Systems EZ-Melt MPA120 automated melting point apparatus. NMR spectra were recorded on NMR Varian Inova $300 \mathrm{MHz}$. UV-VIS spectra were collected on Shimadzu UV-2101 PC double-beam spectrophotometer. Infrared spectra were measured on MettlerToledo ReactIR iC10 spectrometer.

\subsection{General procedure for synthesis of bis-(1,3-diketones) $(1,4)$}

To a three-necked flask equipped with a mechanical stirrer, reflux condenser and drying tube, $50 \mathrm{mmol}$ of ester, $100 \mathrm{~mL}$ of THF and $200 \mathrm{mmol}$ of the base (see Table 1) was added, and the mixture was warmed to the boiling temperature. A mixture of the proper amount of acetophenone (see Table 1) and $25 \mathrm{~mL}$ THF was added dropwise over $30 \mathrm{~min}$, and the formation of a yellow solid was observed. The reaction was rapidly stirred for $8 \mathrm{~h}$. The mixture was cooled to $5^{\circ} \mathrm{C}$ in an ice bath to avoid ester hydrolysis. Upon cooling, the mixture color changed to dark brown. Neutralization of the formed salt of bis-(1,3-diketone) was performed using two methods:

Method 1: Maintaining rapid stirring, $10 \% \mathrm{HCl}$ was added to the reaction mixture until $\mathrm{pH}=7$. During neutralization, the mixture color changed to light-yellow. The neutralized mixture was filtered with a Büchner funnel, and the filtrate was poured into a separatory funnel. The aqueous layer was extracted with methylene chloride. Organic fractions were merged and evaporated. 


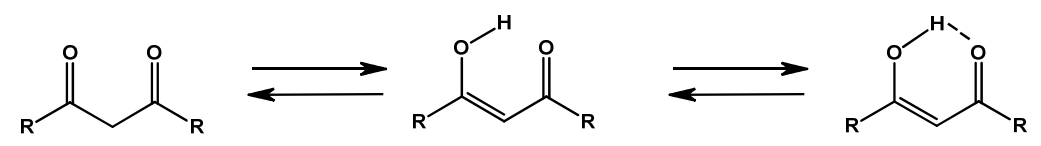

Scheme 1<smiles>[R]Cc1ccc(C(=O)CC(=O)c2ccccc2)cc1</smiles>

Scheme 2

From the resulting solid residue, the main products and byproducts were separated by column chromatography $(100 \%$, $\mathrm{CH}_{2} \mathrm{Cl}_{2}$ ). After several crystallizations from methanol, pure bis(1,3-diketones) were obtained. See Table 1 for yields.

Method 2: Maintaining rapid stirring, $100 \%$ acetic acid was added to the reaction mixture until $\mathrm{pH}=7$. During neutralization, the mixture color changed to light-yellow. The gelatinous precipitate containing by-products was centrifuged, and the solution was concentrated and placed in refrigerator for $24 \mathrm{~h}$. The precipitate that formed was filtered and crystallized from DMF/MeOH $(1: 1 ; \mathrm{v} / \mathrm{v})$ to give pure product. See Table 1 for yields.

1,4-bis-(3-phenyl-3-oxopropionyl)benzene (1): Yellow. M.p.: 177, $197-198^{\circ} \mathrm{C}$ (Ref. [8], 176-177 ${ }^{\circ} \mathrm{C}$ ). IR ( $\left.\nu_{\max }, \mathrm{cm}^{-1}\right): 3060(\mathrm{w})$, 2670 (w), 1596 (m), 1529 (s), 1495 (w), 1301 (s-m), 1237 (m), 1184 (m-w), 1159 (w) 1129 (m-w), 1103 (vw), 1069 (m-w), 1028 (w), $1013(\mathrm{w}), 987(\mathrm{w}), 926(\mathrm{w}), 856$ (m-w), 800 (m-w), 755 (s), $703(\mathrm{w}), 680(\mathrm{~m}) .{ }^{1} \mathrm{H}$ NMR $\left(\mathrm{CDCl}_{3}, 300 \mathrm{MHz}, \delta, \mathrm{ppm}\right):$ $16.82(2 \mathrm{H}, \mathrm{br}, \mathrm{C}(\mathrm{OH})=\mathrm{CH}-\mathrm{CO}), 8.09(4 \mathrm{H}, \mathrm{s}, \operatorname{Ar}-H), 8.02(4 \mathrm{H}, \mathrm{d}$, $J=6.9 \mathrm{~Hz}, \operatorname{Ar}-H), 7.59(2 \mathrm{H}, \mathrm{t} J=7.2 \mathrm{~Hz}, \operatorname{Ar}-H), 7.52(4 \mathrm{H}, \mathrm{t}, J=7.2 \mathrm{~Hz}$, $\mathrm{Ar}-H), 6.92(2 \mathrm{H}, \mathrm{s}, \mathrm{C}(\mathrm{OH})=\mathrm{CH}-\mathrm{CO}) .{ }^{13} \mathrm{C} \mathrm{NMR}\left(\mathrm{CDCl}_{3}, 75 \mathrm{MHz}, \delta\right.$, ppm): 187.0, 183.5 (CO), 138.7, 135.5, 132.8, 128.8, 127.4, $127.3(\mathrm{Ar}-\mathrm{C}), 93.7(\mathrm{C}(\mathrm{OH})=C \mathrm{H}-\mathrm{CO})$. Anal. Calcd. for $\mathrm{C}_{24} \mathrm{H}_{18} \mathrm{O}_{4}$ : C, 77.82; H, 4.90. Found: C, 77.78; H 4.91\%.

1,3-bis-(3-phenyl-3-oxopropionyl)benzene (4): White. M.p.: 159, $173{ }^{\circ} \mathrm{C}$ (Ref. [8] 153-154 ${ }^{\circ} \mathrm{C}$ ). IR ( $\left.\nu_{\max }, \mathrm{cm}^{-1}\right): 3075$ (w), 2672 (w), 1603 (s), 1525 (s), 1484 (s), 1304 (m), 1267 (m), 1241 (m), 1215 (s), 1184 (w), 1159 (w), 1099 (m), 1069 (m), 1024 (m-w), 1002 (m-w), 972 (w), $934(\mathrm{w}), 908(\mathrm{w}), 848(\mathrm{w})$, $804(\mathrm{w}), 759$ (s), $695(\mathrm{~m}), 680(\mathrm{~m}), 654(\mathrm{w}) .{ }^{1} \mathrm{H} \mathrm{NMR}\left(\mathrm{CDCl}_{3}\right.$, $300 \mathrm{MHz}, \delta, \mathrm{ppm}): 16.89(2 \mathrm{H}, \mathrm{br}, \mathrm{C}(\mathrm{OH})=\mathrm{CH}-\mathrm{CO}), 8.15(1 \mathrm{H}, \mathrm{s}$, Ar- $H$ ), 8.18 (1H, d, J=7.8 Hz, Ar- $H$ ), 8.02-8.05 (4H, m, Ar- $H$ )7.497.68(8H, m, Ar- $H), 6.95(2 \mathrm{H}, \mathrm{s}, \mathrm{C}(\mathrm{OH})=\mathrm{CH}-\mathrm{CO}) .{ }^{13} \mathrm{C} \mathrm{NMR}\left(\mathrm{CDCl}_{3}\right.$, $75 \mathrm{MHz}, \delta$, ppm): 186.4, 185.1 (CO), 138.6, 136.5, 133.0, 131.0, 129.4, 129.0, 127.5, $126.0(\mathrm{Ar}-\mathrm{C}), 93.6(\mathrm{C}(\mathrm{OH})=\mathrm{CH}-\mathrm{CO})$. Anal. Calcd. for $\mathrm{C}_{24} \mathrm{H}_{18} \mathrm{O}_{4}$ : C, 77.82; H, 4.90. Found: $\mathrm{C}, 77.75 ; \mathrm{H}, 5.02 \%$.

\subsection{General procedure for synthesis of 1,3-diketones with ester group $(2,5)$}

To the three-necked flask equipped with a mechanical stirrer, reflux condenser and drying tube, $50 \mathrm{mmol}$ of ester, 100 $\mathrm{mL}$ of THF and $30 \%$ solution of sodium methoxide (50 mmol) in methanol was added, and the mixture was warmed to the boiling temperature. The mixture of $33 \mathrm{mmol}$ of acetophenone and $25 \mathrm{~mL}$ of THF was added dropwise over $30 \mathrm{~min}$, and the formation of a yellow solid was observed. The reaction was rapidly stirred for $4 \mathrm{~h}$. The mixture was cooled to $5{ }^{\circ} \mathrm{C}$ in an ice bath to avoid ester hydrolysis. Upon cooling, the mixture color changed to dark brown. Maintaining rapid stirring, to the reaction mixture $10 \% \mathrm{HCl}$ was added until $\mathrm{pH}=7$ was reached. During neutralization, the mixture color changed to lightyellow. The organic layer was separated and evaporated, and the resulting precipitate was filtered and crystallized from methanol to give pure product. Yields: 45\% (2), 42\% (5).

Methyl 4-(3-phenyl-3-oxopropionyl)benzoate (2): White. M.p.: $123-124{ }^{\circ} \mathrm{C}$ (Ref. [10] 123-125 ${ }^{\circ} \mathrm{C}$ ). IR ( $\left.\nu_{\max } \mathrm{cm}^{-1}\right): 3057$ (w), 2966 (w), 1731 (s), 1596 (s-m), 1529 (s), 1506 (s-m), 1443 (s), 1405 (m-w), 1286 (s), 1230 (m), 1196 (m), 1118 (s), 1073 (m), $1061(\mathrm{~m}), 1017(\mathrm{~s}), 960(\mathrm{~m}-\mathrm{w}), 927(\mathrm{w}), 867(\mathrm{~m}), 833(\mathrm{w})$, $804(\mathrm{~m}), 792(\mathrm{~m}), 751(\mathrm{~s}), 706(\mathrm{~m}), 680(\mathrm{~m}) .{ }^{1} \mathrm{H}$ NMR $\left(\mathrm{CDCl}_{3}\right.$, $300 \mathrm{MHz}, \delta, \mathrm{ppm}): 16.79(1 \mathrm{H}, \mathrm{br}, \mathrm{C}(\mathrm{OH})=\mathrm{CH}-\mathrm{CO}), 8.15(2 \mathrm{H}, \mathrm{d}$, $J=8.7 \mathrm{~Hz}, \mathrm{Ar}-H), 7.98-8.07(4 \mathrm{H}, \mathrm{m}, \mathrm{Ar}-\mathrm{H}), 7.59(1 \mathrm{H}, \mathrm{t} J=7.5 \mathrm{~Hz}, \mathrm{Ar}-$ $H), 7.51(2 \mathrm{H}, \mathrm{t} J=7.35 \mathrm{~Hz}, \mathrm{Ar}-H), 6.90(1 \mathrm{H}, \mathrm{s}, \mathrm{C}(\mathrm{OH})=\mathrm{C} H-\mathrm{CO}) 3.97$ (3H, s, $-\mathrm{COOCH} 3) .{ }^{13} \mathrm{C} \mathrm{NMR}\left(\mathrm{CDCl}_{3}, 75 \mathrm{MHz}, \delta, \mathrm{ppm}\right): 187.1$, 183.5 (CO), $166.3\left(\mathrm{COOCH}_{3}\right), 139.2,135.4,133.2,132.8,129.8$, 128.6, $127.3, \quad 127.0 \quad(\mathrm{Ar}-\mathrm{C}), \quad 93.8 \quad(\mathrm{C}(\mathrm{OH})=C \mathrm{H}-\mathrm{CO}), \quad 52.4$ $\left(\mathrm{COOCH}_{3}\right)$. Anal. Calcd. for $\mathrm{C}_{17} \mathrm{H}_{14} \mathrm{O}_{4}$ : C, 72.33; H, 5.00. Found: C, 72.30; $\mathrm{H}, 5.04 \%$.

Methyl 3-(3-phenyl-3-oxopropionyl)benzoate (5): White. M.p.: $82-83{ }^{\circ} \mathrm{C}$. IR $\left(v_{\max }, \mathrm{cm}^{-1}\right): 3072$ (w), 2956 (w), 2661 (vw), 1727 (s), 1607 (s), 1559 (s), 1480 (s), 1439 (s), 1301 (s), 1263 (s), 1222 (s), 1121 (m), 1076 (m-w), 1065 (w), 1028 (w), 1002 (w), $983(\mathrm{~m}-\mathrm{w}), 930(\mathrm{w}), 863(\mathrm{w}), 811(\mathrm{w}), 755(\mathrm{~s}), 721(\mathrm{~m})$ $703(\mathrm{~m}), 684(\mathrm{~m}), 662(\mathrm{w}) .{ }^{1} \mathrm{H}$ NMR $\left(\mathrm{CDCl}_{3}, 300 \mathrm{MHz}, \delta, \mathrm{ppm}\right):$ $16.84(1 \mathrm{H}, \mathrm{br}, \mathrm{C}(\mathrm{OH})=\mathrm{CH}-\mathrm{CO}), 8.63(1 \mathrm{H}, \mathrm{s}, \operatorname{Ar}-H), 8.22(2 \mathrm{H}, \mathrm{t}$ $\mathrm{J}=7.2 \mathrm{~Hz}, \mathrm{Ar}-H), 8.02(2 \mathrm{H}, \mathrm{d}, J=6.8 \mathrm{~Hz}, \mathrm{Ar}-H), 7.48-7.63(4 \mathrm{H}, \mathrm{m}$, $\mathrm{Ar}-\mathrm{H}), 6.92(1 \mathrm{H}, \mathrm{s}, \mathrm{C}(\mathrm{OH})=\mathrm{C} H-\mathrm{CO}), 3.99\left(3 \mathrm{H}, \mathrm{s},-\mathrm{COOCH}_{3}\right) .{ }^{13} \mathrm{C}$ NMR $\left(\mathrm{CDCl}_{3}, 75 \mathrm{MHz}, \delta, \mathrm{ppm}\right):$ 186.5, 184.7 (CO), 166.6 $\left(\mathrm{COOCH}_{3}\right), 136.2,135.5,133.4,132.9,131.7,131.0,129.2$ 129.0, 128.5, $127.5 \quad(\mathrm{Ar}-\mathrm{C}), \quad 93.5 \quad(\mathrm{C}(\mathrm{OH})=\mathrm{CH}-\mathrm{CO}), \quad 52.7$ ( $\mathrm{COOCH}_{3}$ ). Anal. Calcd. for $\mathrm{C}_{17} \mathrm{H}_{14} \mathrm{O}_{4}$ : C, 72.33; H, 5.00. Found: C, 72.15; H, 5.09\%.

Table 1. Yields and substrates ratio in bis-(1,3-diketone) synthesis.

\begin{tabular}{llll}
\hline Product & Base & AcPh:Ester [mol:mol] & Yield [\%] \\
\hline 1 & $\mathrm{NaOMe}$ & 2.8 & $50^{\mathrm{a}}$ \\
1 & $\mathrm{NaH}$ & 2.8 & $61^{\mathrm{a}}$ \\
1 & $\mathrm{NaOMe}$ & 4,0 & $51^{\mathrm{a}}, 38^{\mathrm{b}}$ \\
1 & $\mathrm{NaH}$ & 4.0 & $61^{\mathrm{a}}, 49^{\mathrm{b}}$ \\
2 & $\mathrm{NaOMe}$ & 2.8 & $28^{\mathrm{a}}$ \\
2 & $\mathrm{NaH}$ & 2.8 & $29^{\mathrm{a}}$ \\
2 & $\mathrm{NaOMe}$ & 4.0 & $2^{\mathrm{a}}$ \\
2 & $\mathrm{NaH}$ & 4.0 & $2^{\mathrm{a}}$ \\
4 & $\mathrm{NaOMe}$ & 4.0 & $44^{\mathrm{b}}$ \\
4 & $\mathrm{NaH}$ & 4.0 & $64^{\mathrm{b}}$ \\
\hline
\end{tabular}
a Determined by HPLC after neutralization with $10 \% \mathrm{HCl}$ (Method 1).

${ }^{b}$ Separated product after neutralization with $100 \% \mathrm{CH}_{3} \mathrm{COOH}$ (Method 2).

\subsection{General procedure for synthesis of 1,3-diketones with carboxylic group $(3,6)$}

To the round bottom flask proper ester $(2,5)(3,5 \mathrm{mmol})$, $15 \mathrm{~mL}$ of THF and a solution of LiOH. $\mathrm{H}_{2} \mathrm{O}(35 \mathrm{mmol})$ in $15 \mathrm{~mL}$ $\mathrm{H}_{2} \mathrm{O}$ was added. The mixture was stirred with magnetic stirrer for $6 \mathrm{~h}$ at room temperature. To the separated aqueous layer, $3 \% \mathrm{HCl}(52 \mathrm{mmol})$ was added. 


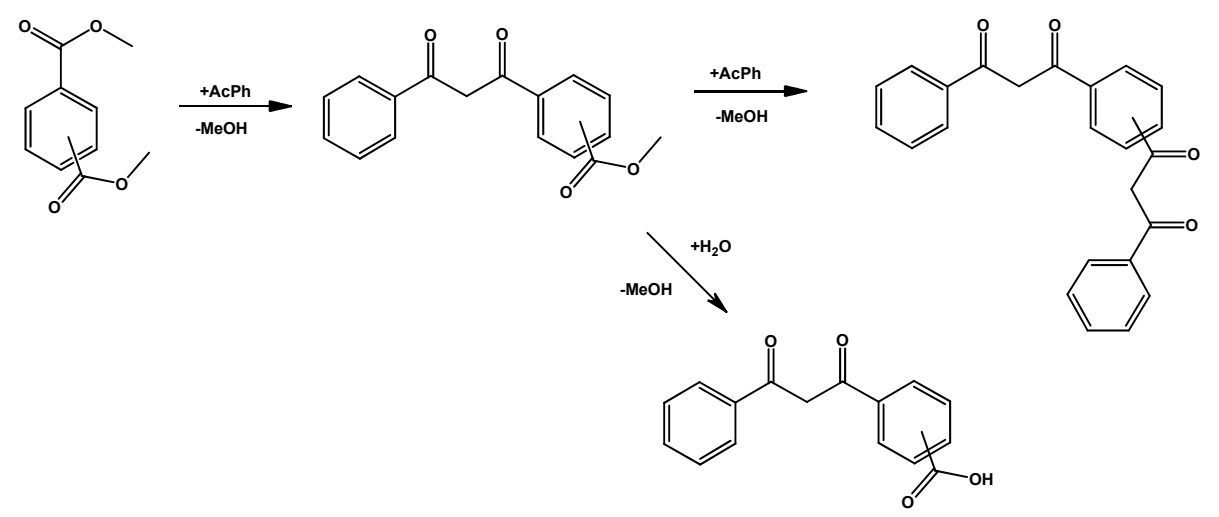

Scheme 3

The resulting white solid was filtered and crystallized from ethanol to give pure product. Yields: $67 \%(3), 73 \%(6)$.

4-(3phenyl-3-oxopropionyl)benzoic acid (3): White. M.p.: $235^{\circ} \mathrm{C}$. IR ( $\left.v_{\max }, \mathrm{cm}^{-1}\right): 3027(\mathrm{~m}), 2833(\mathrm{~m}), 2684(\mathrm{~m}), 1682(\mathrm{~s})$, 1592 (m), 1577 (w), 1532 (m), $1510(\mathrm{~m}), 1432$ (m), $1327(\mathrm{w})$, 1293 (s), $1230(\mathrm{w}), 1189(\mathrm{w}), 1155(\mathrm{vw}), 1121(\mathrm{~m}), 1103(\mathrm{w})$, $1073(\mathrm{w}), 1058(\mathrm{w}), 1017(\mathrm{w}), 982(\mathrm{w}), 931(\mathrm{~m}), 871(\mathrm{~m}), 807$ $(\mathrm{w}), 781(\mathrm{~m}), 751(\mathrm{~s}), 714(\mathrm{~m}), 680(\mathrm{~m}) .{ }^{1} \mathrm{H}$ NMR (DMSO- $d_{6}, 300$ $\mathrm{MHz}, \delta, \mathrm{ppm}): 17.04(1 \mathrm{H}, \mathrm{br}, \mathrm{C}(\mathrm{OH})=\mathrm{CH}-\mathrm{CO}), 13.34(1 \mathrm{H}, \mathrm{br},-$ $\mathrm{COOH}$ ), 8.27 (2H, d, J=8.4 Hz, Ar- $H$ ), 8.19 (2H, d, J=7.3 Hz, Ar- $H$ ), $8.08(2 \mathrm{H}, \mathrm{d}, J=8.4 \mathrm{~Hz}, \mathrm{Ar}-H), 7.67(1 \mathrm{H}, \mathrm{t}, J=7.4 \mathrm{~Hz}, \mathrm{Ar}-H), 7.57$ $(2 \mathrm{H}, \mathrm{t}, J=7.4 \mathrm{~Hz}, \mathrm{Ar}-H), 7.42(1 \mathrm{H}, \mathrm{s}, \mathrm{C}(\mathrm{OH})=\mathrm{CH}-\mathrm{CO}) .{ }^{13} \mathrm{C}$ NMR (DMSO- $\left.d_{6}, 75 \mathrm{MHz}, \delta, \mathrm{ppm}\right): 186.7,183.1(\mathrm{CO}), 166.6(\mathrm{COOH})$, 138.1, 134.6, 134.2, 133.3, 129.6, 128.9, 127.6, 127.5 (Ar-C), $94.1(\mathrm{C}(\mathrm{OH})=C \mathrm{H}-\mathrm{CO})$. Anal. Calcd. for $\mathrm{C}_{16} \mathrm{H}_{12} \mathrm{O}_{4}$ : C, 71.64; $\mathrm{H}, 4.51$. Found: $\mathrm{C}, 71.55 ; \mathrm{H}, 4.64 \%$.

3-(3-phenyl-3-oxopropionyl)benzoic acid (6): White. M.p.: 195-196 ${ }^{\circ} \mathrm{C}$. IR ( $\left.v_{\max }, \mathrm{cm}^{-1}\right): 2975(\mathrm{w}), 2841(\mathrm{~m}), 2672(\mathrm{w}), 1682$ (s), $1611(\mathrm{~m}), 1532(\mathrm{~m}), 1491(\mathrm{w}), 1446(\mathrm{~m}), 1308(\mathrm{~s}), 1230$ (m), 1185 (w), 1099 (m-w), 1069 (m-w), $1028(\mathrm{w}), 1002(\mathrm{w})$, $946(\mathrm{~m}), 930(\mathrm{~m}), 826(\mathrm{w}), 804(\mathrm{w}), 777(\mathrm{vw}), 748(\mathrm{~s}), 706(\mathrm{~m}-$ w), $680(\mathrm{~m}), 665(\mathrm{~m}) .{ }^{1} \mathrm{H}$ NMR (DMSO- $\left.d_{6}, 300 \mathrm{MHz}, \delta, \mathrm{ppm}\right):$ $17.14(1 \mathrm{H}, \mathrm{br}, \mathrm{C}(\mathrm{OH})=\mathrm{CH}-\mathrm{CO}), 13.32(1 \mathrm{H}, \mathrm{br},-\mathrm{COOH}), 8.62(1 \mathrm{H}$, s, $\operatorname{ArH}), 8.44(1 \mathrm{H}, \mathrm{d}, J=7.8 \mathrm{~Hz}, \mathrm{Ar}-H), 8.15-8.23(3 \mathrm{H}, \mathrm{m}, \mathrm{Ar}-H)$, 7.62-7.74 (2H, m, Ar- $H), 7.57(2 \mathrm{H}, \mathrm{t}, J=7.4 \mathrm{~Hz}, \mathrm{Ar}-H), 7.42(1 \mathrm{H}, \mathrm{s}$, $\mathrm{C}(\mathrm{OH})=\mathrm{CH}-\mathrm{CO}$ ). ${ }^{13} \mathrm{C}$ NMR (DMSO- $\left.d_{6}, 75 \mathrm{MHz}, \delta, \mathrm{ppm}\right): 186.6$, 184.8 (CO), $167.4(\mathrm{COOH}), 135.7,135.2,134.1,133.9,132.4$, 132.3, 130.0, 129.6, 128.5, $128.3(\mathrm{Ar}-\mathrm{C}), 94.3(\mathrm{C}(\mathrm{OH})=\mathrm{CH}-\mathrm{CO})$. Anal. Calcd. for $\mathrm{C}_{16} \mathrm{H}_{12} \mathrm{O}_{4}$ : C, 71.64; H, 4.51. Found: C, 71.58; H, $4.40 \%$.

\subsection{Synthesis of 1,3-diphenylpropane-1,3-dione (7)}

To a three-necked flask equipped with a mechanical stirrer, reflux condenser and drying tube, $60 \mathrm{mmol}$ of methyl benzoate, $100 \mathrm{~mL}$ of THF and $30 \%$ solution of sodium methoxide ( 60 $\mathrm{mmol}$ ) in methanol was added and mixture was warmed to the boiling temperature. A mixture of $50 \mathrm{mmol}$ of acetophenone and $25 \mathrm{~mL}$ of THF was added dropwise over $30 \mathrm{~min}$, and the formation of yellow solid was observed. The reaction was rapidly stirrred for $4 \mathrm{~h}$. The mixture was cooled to $5^{\circ} \mathrm{C}$, and $10 \% \mathrm{HCl}$ was added until the $\mathrm{pH}=7$ was reached. The organic layer was separated and evaporated, and the resulting precipitate was filtered and crystallized from ethanol to give pure product. Yield: $80 \%$.

1,3-diphenylpropane-1,3-dione (7): White. M.p.: 77-78 ${ }^{\circ} \mathrm{C}$. IR ( $\left.v_{\max }, \mathrm{cm}^{-1}\right): 3131(\mathrm{w}), 3069(\mathrm{~m}), 2990(\mathrm{w}), 2665(\mathrm{w}), 1600(\mathrm{~s})$, 1536 (s), 1513 (s), 1488 (s), 1469 (s), 1435 (m), 1308 (s), 1267 (s), 1230 (s), 1185 (m), $1166(\mathrm{w}), 1102$ (m), 1065 (m), 1028 (m), $1002(\mathrm{~m}), 976(\mathrm{w}), 931(\mathrm{~m}), 897(\mathrm{w}), 845(\mathrm{w}), 815(\mathrm{w})$, 789 (w-m), 755 (s), 736 (s), 706 (s), 680 (s). ${ }^{1} \mathrm{H}$ NMR ( $\mathrm{CDCl}_{3}$, $300 \mathrm{MHz}, \delta, \mathrm{ppm}): 16.90(1 \mathrm{H}, \mathrm{br}, \mathrm{C}(\mathrm{OH})=\mathrm{CH}-\mathrm{CO}) 7.97-8.01(4 \mathrm{H}$, $\mathrm{m}, \mathrm{Ar}-H)$, 7.44-7.58 $(6 \mathrm{H}, \mathrm{m}, \mathrm{Ar}-\mathrm{H}), 6.86(1 \mathrm{H}, \mathrm{s}, \mathrm{C}(\mathrm{OH})=\mathrm{C} H-\mathrm{CO})$. ${ }^{13} \mathrm{C}$ NMR ( $\left.\mathrm{CDCl}_{3}, 75 \mathrm{MHz}, \delta, \mathrm{ppm}\right): 185.9$ (CO), 135.7, 132.7, 128.9, $127.4(\mathrm{Ar}-\mathrm{C}), 93.3(\mathrm{C}(\mathrm{OH})=\mathrm{CH}-\mathrm{CO})$. Anal. Calcd. for $\mathrm{C}_{15} \mathrm{H}_{12} \mathrm{O}_{2}: \mathrm{C}, 80.34 ; \mathrm{H}, 5.39$. Found: C, 80.39; $\mathrm{H}, 5.42 \%$.

\subsection{Melting point}

During melting point determination, the transformation in the capillary was observed approximately $20{ }^{\circ} \mathrm{C}$ below the typical melting point. The substance was becoming muddy and probably partially melted. The material remained in this state without change until the appropriate melting point temperature was achieved. The existence of two melting points is probably connected with the formation of intramolecular hydrogen bonds and two possible crystalline forms, which may coexist in various ratios depending on which solvent was used for crystallization. Crystallization from DMF/MeOH leads to the formation of large crystals of product containing mainly the form with the higher melting point.

\section{Results and discussion}

Bis-(1,3-diketones) were obtained by the crossed-Claisen condensation of esters of phthalic acid isomers and acetophenone (Scheme 3) - a modified procedure first reported in [8]. Reactions were conducted in tetrahydrofuran (THF) with a $30 \%$ solution of sodium methoxide as a base. Besides bis-(1,3diketones), the intermediate product with one unreacted ester group was found in the reaction mixture (Scheme 3). We investigated the influence of the quantity of acetophenone on bis-(1,3-diketone) yield. While an excess of acetophenone decreases the amount of intermediate product, it has little effect on the yield of bis-(1,3-diketone). After neutralization of the reaction mixture, we also found 1,3-diketones with carboxylic groups that are formed via hydrolysis of the ester group of the intermediate product (Scheme 3).

Thus, we obtained three diketones from dimethyl $p$-phthalate: 1,4-bis-(3-phenyl-3-oxopropionyl)benzene (1), methyl 4-(3-phenyl-3-oxopropionyl)benzoate (2), 4-(3-phenyl3-oxopropionyl)benzoic acid (3), and three diketones from dimethyl $m$-phthalate: 1,3-bis-(3-phenyl-3-oxopropionyl) benzene (4), methyl 3-(3-phenyl-3-oxopropionyl)benzoate (5), 3-(3phenyl-3-oxopropionyl)benzoic acid (6). For comparison, we also obtained 1,3-diphenylpropane-1,3-dione (7) from methyl benzoate (Scheme 4). 


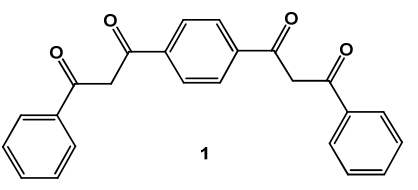<smiles>COC(=O)c1ccc(C(=O)CC(=O)c2ccc(C(=O)CC(=O)c3ccccc3)cc2)cc1C(=O)CC(=O)c1ccc(C(=O)CC(=O)c2ccccc2)cc1</smiles><smiles>O=C(CC(=O)c1cccc(C(=O)CC(=O)c2ccccc2)c1)c1ccccc1</smiles>

Scheme 4

Yields are listed in Table 1. HPLC analysis of the obtained compounds showed that the reaction provides almost complete conversion of the phthalates. The main product after hydrolysis is proper phthalic acid, which is probably formed during hydrolysis with $10 \%$ hydrochloric acid. Because of the extremely low solubility of phthalic acids and diketones with carboxylic acid groups $(3,6)$ and the relatively low solubility of bis-diketones $(\mathbf{1}, \mathbf{4})$ (Table 2), these products are difficult to separate. The separation process described in [8], repeated in later publications [5,7], gave contaminated product with low yields.

Table 2. Solubility in g/100 g of solvent of 1, 2 and 3.

\begin{tabular}{|c|c|c|c|}
\hline \multirow[b]{2}{*}{ Product } & \multirow[b]{2}{*}{ Solvent } & \multicolumn{2}{|c|}{ Solubility [g/100 g of solvent } \\
\hline & & at $21{ }^{\circ} \mathrm{C}$ & at boiling temp. \\
\hline 1 & Benzene & 0.22 & \\
\hline 1 & Acetone & - & $2.40\left(56^{\circ} \mathrm{C}\right)$ \\
\hline 1 & $\mathrm{CH}_{2} \mathrm{Cl}_{2}$ & 1.17 & $2.27\left(39^{\circ} \mathrm{C}\right)$ \\
\hline 1 & $\mathrm{MeOH}$ & 0.08 & $0.10\left(65^{\circ} \mathrm{C}\right)$ \\
\hline 1 & THF & 4.42 & $12.68\left(66^{\circ} \mathrm{C}\right)$ \\
\hline 1 & DMF & 4.20 & - \\
\hline 1 & $\mathrm{MeOH} / \mathrm{DMF}(1 / 1, \mathrm{v} / \mathrm{v})$ & 0.57 & $4.07\left(81^{\circ} \mathrm{C}\right)$ \\
\hline 2 & $\mathrm{CH}_{2} \mathrm{Cl}_{2}$ & 27.87 & - \\
\hline 2 & $\mathrm{MeOH}$ & 0.56 & $5.50\left(65^{\circ} \mathrm{C}\right)$ \\
\hline 3 & Acetone & 0.02 & - \\
\hline 3 & $\mathrm{CH}_{2} \mathrm{Cl}_{2}$ & 0.41 & - \\
\hline 3 & $\mathrm{MeOH}$ & 0.83 & - \\
\hline
\end{tabular}

Therefore, we carried out several syntheses (method 2), using glacial acetic acid in the hydrolysis step, to prevent formation of diketones with carboxylic acid groups. Using this method, we obtained the by-products as a gelatinous precipitate. After centrifugation and concentration, a relatively pure product precipitated from solution. To achieve high purity, we crystallized the products from a mixture of dimethylformamide and methanol $(1: 1, \mathrm{v} / \mathrm{v})$, a protocol which required significantly less solvent and increased the crystallization yield relative to that obtained using only methanol as solvent. The use of sodium hydride instead of sodium methoxide increased the yield of bis-(1,3-diketones).

When $o$-phthalate was used as the ester in this synthesis, we did not obtain the desired products. However, we isolated a compound that was identified by ${ }^{1} \mathrm{H}$ NMR as mixture of $E$ and $Z$ isomers of 3-(2'-oxo-2'-phenyl-ethylidene)-3H-isobenzofurane1 -one in a ratio of $5: 3$. This compound probably results from intramolecular transestrification of the intermediate product (Scheme 5).<smiles>COC(=O)c1ccccc1/C(=C/C(=O)c1ccccc1)Cc1cccc(C(=O)/C=C2\OC(=O)c3cc(CO)ccc32)c1</smiles>

Scheme 5

\subsection{UV absorption}

We investigated the UV absorption spectra of the generated compounds in anhydrous ethanol $(\lambda=210-450 \mathrm{~nm})$, acetonitrile $(\lambda=210-450 \mathrm{~nm})$ and $n$-heptane $(\lambda=200-450 \mathrm{~nm})$. The concentration of all solutions was $50 \pm 0.5 \mu \mathrm{mol} / \mathrm{dm}^{3}$. Because of their low solubility, the spectra of some compounds were not investigated in $n$-heptane. Molar absorption coefficients and absorption maxima are given in Tables 3 and 4 . The UV spectra of all obtained compounds in ethanol are given in Figures 1 and 2.

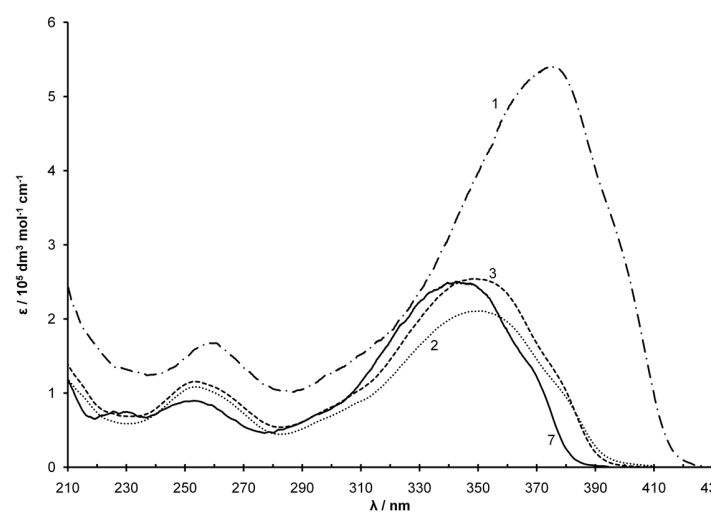

Figure 1. Absorption spectra of 1, 2, 3 and 7 . Ethanol, $0.5 \mathrm{~cm}, 5 \times 10^{-5} \mathrm{~mol} / \mathrm{dm}^{3}$.

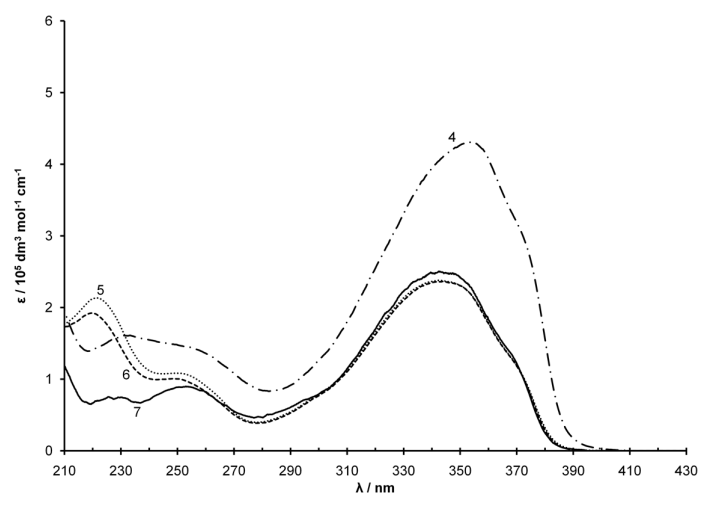

Figure 2. Abosrption spectra of 4, 5, 6 and 7 . Ethanol, $0.5 \mathrm{~cm}, 5 \times 10^{-5} \mathrm{~mol} / \mathrm{dm}^{3}$.

All investigated compounds absorb strongly in the range of $\lambda_{1}=280-400 \mathrm{~nm}$. In addition, two weaker absorption bands can be distinguished: $\lambda_{2}=230-280 \mathrm{~nm}, \lambda_{3}=200-230 \mathrm{~nm}$. However, only 7 and compounds synthesized from methyl terephthalate (1-3) have distinct peaks in band $\lambda_{2}$; peaks of 5 and $\mathbf{6}$ in this range are barely noticeable, covered by peaks in third band, which come probably from non-conjugated carboxylic group. We found that in the first band, the molar absorption coefficient of $\mathbf{1}$ is over two times higher than that of $\mathbf{7}$, and the absorption maximum is strongly red-shifted. Such strong hyperchromic and bathochromic $(\Delta \lambda \approx 33 \mathrm{~nm})$ effects are probably caused by the interaction of two conjugated 1,3dicarbonyl moieties. 
Table 3. Molar absorption coefficients and absorption maxima of synthesized compounds in the range of $\lambda=280-400 \mathrm{~nm}$

\begin{tabular}{|c|c|c|c|c|c|c|}
\hline \multirow{2}{*}{ Product } & \multicolumn{3}{|c|}{$\lambda_{\max } / \mathbf{n m}$} & \multicolumn{3}{|c|}{$\varepsilon_{\max } / \mathrm{dm}^{3} \mathrm{~mol}^{-1} \mathrm{~cm}^{-1}$} \\
\hline & Ethanol & $\mathrm{CH}_{3} \mathrm{CN}$ & n-Heptane & Ethanol & $\mathrm{CH}_{3} \mathrm{CN}$ & n-Heptane \\
\hline$\overline{1}$ & 375.3 & 374.5 & - & 54019 & 44979 & - \\
\hline 2 & 350.4 & 347.0 & 342.7 & 21066 & 20373 & 19748 \\
\hline 3 & 348.7 & 346.5 & - & 25409 & 23636 & - \\
\hline 4 & 354.3 & 351.6 & - & 43142 & 38806 & - \\
\hline 5 & 342.5 & 341.8 & 337.5 & 23789 & 22622 & 22686 \\
\hline 6 & 343.1 & 341.2 & - & 23636 & 23333 & - \\
\hline 7 & 342.4 & 342.0 & 335.6 & 25037 & 23741 & 23629 \\
\hline
\end{tabular}

Table 4. Molar absorption coefficients and absorption maxima of synthesized compounds in the range of $\lambda=200-280 \mathrm{~nm}$.

\begin{tabular}{|c|c|c|c|c|c|c|}
\hline \multirow{2}{*}{ Product } & \multicolumn{3}{|c|}{$\lambda_{\max } / \mathbf{n m}$} & \multicolumn{3}{|c|}{$\varepsilon_{\max } / \mathbf{d m}^{3} \mathrm{~mol}^{-1} \mathrm{~cm}^{-1}$} \\
\hline & Ethanol & $\mathrm{CH}_{3} \mathrm{CN}$ & n-Heptane & Ethanol & $\mathrm{CH}_{3} \mathrm{CN}$ & n-Heptane \\
\hline 1 & 258.8 & 256.8 & & 16740 & 14980 & 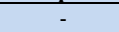 \\
\hline 2 & 253.2 & 252.2 & 252.2 & 10830 & 11199 & 10735 \\
\hline 3 & 253.2 & 251.8 & - & 11547 & 12861 & - \\
\hline 4 & 233.2 & 233.6 & - & 16111 & 16410 & - \\
\hline 5 & 249.7 & 246.6 & 247.7 & 10846 & 11380 & 10850 \\
\hline & 221.6 & 219.6 & 221.0 & 21333 & 21460 & 21352 \\
\hline 6 & 249.0 & 247.8 & - & 10067 & 11619 & - \\
\hline & 219.8 & 219.2 & - & 19222 & 21958 & - \\
\hline 7 & 253.0 & 249.6 & 248.6 & 8979 & 9444 & 9884 \\
\hline
\end{tabular}

Table 5. Enol percentages and keto-enol tautomerism equilibrium constants of synthesized compounds.

\begin{tabular}{|c|c|c|c|c|c|c|c|c|}
\hline \multirow{2}{*}{ Product } & \multicolumn{4}{|c|}{ Enol form contents [\%] } & \multicolumn{4}{|c|}{$\mathbf{K}_{\mathbf{T}}$} \\
\hline & DMSO- $_{6}$ & Acetone- $d_{6}$ & $\mathrm{CDCl}_{3}$ & $\mathrm{C}_{6} \mathrm{D}_{6}$ & DMSO-d $_{6}$ & Acetone- $d_{6}$ & $\mathrm{CDCl}_{3}$ & $\mathrm{C}_{6} \mathrm{D}_{6}$ \\
\hline$\overline{1}$ & 95.7 & 97.9 & 98.2 & $>99.9$ & 22 & 46 & 53 & $>999$ \\
\hline 2 & 95.4 & 98.0 & $>>99.9$ & $>99.9$ & 21 & 49 & $>999$ & $>999$ \\
\hline 3 & 95.1 & 95.3 & 98.3 & $>99.9$ & 20 & 20 & 57 & $>999$ \\
\hline 4 & 92.7 & 97.6 & 96.8 & $>99.9$ & 13 & 41 & 30 & $>999$ \\
\hline 5 & 92.7 & 97.0 & 97.1 & $>99.9$ & 13 & 32 & 33 & $>999$ \\
\hline 6 & 93.1 & 96.7 & 97.8 & $>99.9$ & 13 & 29 & 45 & $>999$ \\
\hline 7 & 94.0 & 97.7 & 97.8 & 99.9 & 16 & 42 & 45 & 999 \\
\hline
\end{tabular}

Table 6. Chemical shifts of characteristic protons of synthesized compounds*.

\begin{tabular}{|c|c|c|c|c|c|c|c|c|c|c|c|c|}
\hline \multirow{3}{*}{ Product } & \multicolumn{12}{|c|}{ Chemical shift referenced against TMS / ppm } \\
\hline & \multicolumn{4}{|c|}{$\mathrm{C}(\mathrm{O} \underline{\mathrm{H}})=\mathrm{CHCO}$} & \multicolumn{4}{|c|}{$\mathrm{C}(\mathrm{OH})=\mathrm{CHCO}$} & \multicolumn{4}{|c|}{$\mathrm{CO}-\underline{\mathrm{CH}}_{2}-\mathrm{CO}$} \\
\hline & D & $\mathbf{A}$ & $\mathbf{C}$ & B & D & $\mathbf{A}$ & $\mathbf{C}$ & B & D & $\mathbf{A}$ & $\mathbf{C}$ & B \\
\hline 1 & 17.11 & 17.14 & 16.82 & 16.33 & 7.48 & 7.37 & 6.92 & 6.31 & 4.98 & 4.91 & 4.69 & - \\
\hline 2 & 17.01 & 17.08 & 16.79 & 17.21 & 7.42 & 7.33 & 6.90 & 6.22 & 4.94 & 4.89 & - & - \\
\hline 3 & 17.04 & 17.10 & 16.74 & 17.20 & 7.42 & 7.35 & 6.92 & 6.20 & 4.94 & 4.90 & 4.68 & - \\
\hline 4 & 17.18 & 17.29 & 16.89 & 17.65 & 7.47 & 7.41 & 6.93 & 6.64 & 5.02 & 4.98 & 4.73 & - \\
\hline 5 & 17.08 & 17.21 & 16.85 & 17.60 & 7.47 & 7.35 & 6.92 & 6.59 & 5.02 & 4.93 & 4.67 & - \\
\hline 6 & 17.14 & 17.20 & 16.83 & 17.56 & 7.42 & 7.35 & 6.92 & 6.59 & 4.95 & 4.92 & 4.71 & - \\
\hline 7 & 17.21 & 17.27 & 16.90 & 17.74 & 7.36 & 7.27 & 6.86 & 6.61 & 4.89 & 4.84 & 4.63 & 4.10 \\
\hline
\end{tabular}

While hyperchromic and bathochromic effects in this band are present with 4, they are not as strong as those observed with $\mathbf{1}$. This finding results from the lack of conjugation between the dicarbonyl groups through the aromatic ring. Intermediate products ( 2 and $\mathbf{5})$ and by-products ( 3 and $\mathbf{6})$ do not exhibit the significant spectral effects observed with bis-(1,3diketones), and their spectra are similar to that of 7. However, we observed small bathochromic effects for $2(\Delta \lambda \approx 8 \mathrm{~nm})$ and $3(\Delta \lambda \approx 6 \mathrm{~nm})$, which arise from the conjugation of the 1,3dicarbonyl group with ester or carboxylic acid groups.

\subsection{Keto-enol tautomerism}

We determined the enol percentage of each diketone by recording their ${ }^{1} \mathrm{H}$ NMR spectra at ambient temperature in four solvents: DMSO- $d_{6}$, acetone- $d_{6}, \mathrm{CDCl}_{3}$ and benzene- $d_{6}$. The ketoenol equilibrium constant was calculated using the formula: $\mathrm{K}_{\mathrm{T}}$ $=[$ enol $] /[$ keto $]$.

The concentration of all solutions was $100 \pm 10 \mathrm{mmol} / \mathrm{dm}^{3}$. Enol percentages and keto-enol tautomerism constants are given in the Table 5. Chemical shifts of the characteristic protons are given in Table 6. Influence of solvent is slight; however, the equilibrium is increasingly shifted to the keto form as solvent polarity is increased. In deuterated benzene, the equilibrium is shifted to the enol form to such an extent that a peak corresponding to the characteristic protons of the keto form was not observed (except 7).

\section{Conclusion}

We investigated the UV-absorption and keto-enol tautomerism of seven 1,3-dicarbonyl compounds. The ketoenol equilibrium constant of all compounds suggests that the equilibrium favors the enol form. With increasing solvent polarity, the equilibrium slightly shifts to the keto form, a finding which probably results from the association of polar solvent with the keto tautomers. Keto tautomers are more polar than the pseudo-cyclic, intramolecularly-bonded enol tautomers. Domination of the enol tautomer results in strong absorption of radiation in the UV-A range by all investigated compounds, regardless of the solvent used. The absorption profile of the aromatic 1,3-diketones with carboxylic acid and ester groups is similar to that of 1,3-diphenylpropane-1,3-dione (7). However, aromatic bis-(1,3-diketones) show strong bathochromic and hyperchromic effects which result from the presence of two 1,3-dicarbonyl moieties. The strongest 
hyperchromic effect is observed for $\mathbf{1}$, where the dicarbonyl groups are conjugated through the aromatic ring. This conjugation also causes the strong bathochromic shift and absorption in visible range of the radiation. This effect on the absorption profile of $\mathbf{1}$ gives rise to its yellow color, which obviates some of its applications. In the case of $\mathbf{4}$, we observed a somewhat smaller, but still very strong hyperchromic effect, with significantly smaller bathochromic effects resulting from the non-conjugated dicarbonyl groups. Because of its better absorption properties in comparison to other 1,3-diketones, compound $\mathbf{4}$ has a chance to become a promising future substitute for currently used sun-protective agents.

\section{Acknowledgement}

This work was supported by the European Community from the European Social Fund within the RFSD2 project.

\section{References}

[1]. Lim, H. W.; Draelos, Z. D. In Clinical Guide to Sunscreens and Photoprotection; Informa Healthcare USA, Inc., New York, 2009.

[2]. Zawadiak, J.; Mrzyczek, M. Spectrochim. Acta, Part A 2010, 75, 925929.

[3]. Wypych, G. In PVC Degradation \& Stabilization; $2^{\text {nd }}$ Edition, ChemTec Publishing, Toronto, 2008.

[4]. Przybyszewska, M.; Zaborski, M.; Jakubowski, B.; Zawadiak, J. Express Polymer Lett. 2009, 3(4), 256-266.

[5]. Clegg, J. K.; Bray, D. J.; Gloe, K.; Gloe, K.; Jolliffe, K. A.; Lawrance, G. A.; Lindoy, L. F.; Meehan, G. V.; Wenzel, M. Dalton Trans. 2008, 10, 13311340.

[6]. Soldatov, D. V.; Zanina, A. S.; Enright, G. D.; Ratcliffe, C. I.; Ripmeester, J. A. Cryst. Growth Des. 2003, 3(6), 1005-1013.

[7]. Bao-Li, A.; Chuan-Wei, H.; Hong-Liang, M.; Qing-Yi, P.; Ming-Xin, L. J. Lumin. 2007, 127, 297-301.

[8]. Martin, D. F.; Shamma, M.; Fernelius, W. J. Am. Chem. Soc. 1958, 80(18), 4891-4895.

[9]. Xuan, W. M.; Zou, F.; Chen, L. Q.; Fang, X. M.; Lian, W.; Zhang H. Acta Phys. Chim. Sin. 2008, 24(6), 955-960.

[10]. Adam, W.; Kita, F.; Harrer, H. M.; Nau, W. M.; Zipf, R. J. Org. Chem. 1996, 61, 7056-7065. 